\title{
CORRESPONDENCE
}

\section{EYE DISEASES IN AFRICAN CHILDREN}

\section{To the Editorial Committee of the British Journal of OpHTHALMOLOGY}

SIRS,-With reference to D. S. McLaren's interesting letter (British Journal of Ophthalmology, 1959, 43, 62), where he criticises that part of my paper on "Eye diseases in African Children" which is concerned with the nature of the ocular manifestations of avitaminosis A, I do not think he has altogether appreciated the general nature of that paper. It was never intended to be anything other than what the title suggests. Supporting data were deliberately withheld. It seems to me that some of Dr. McLaren's statements, moreover, parallel mine in their arbitrariness! Nevertheless, I symphathize with him. There is no doubt that the exasperation which this subject induces in us all is due to our lack of knowledge, a lack which no text-book admits or suggests. With this in view I have spent the last 18 months in India with six colleagues working on a 12-point programme the theme of which was "Vitamin A and ocular health". The most important of the papers now ready for publication is entitled "Re-assessment of the Ocular Manifestations of Avitaminosis A". Here most, if not all, the points raised by Dr. McLaren receive careful attention. In fairness to my earlier African paper, the findings in India largely confirm those in Africa, strengthening the claim of the former to be an important document.

LARCHDOWN FARM,

Yours faithfully,

CheCKendon, OxON.

F. C. RODGer.

February 10, 1959.

\section{BOOK REVIEWS}

The Eye: A Clinical and Basic Science Book. By E. H. Bedrossian. 1958. Pp. xxix and 340, 52 figs, 2 col. pl. Thomas, Springfield, Ill. (82s. 6d.)

After a careful perusal of this book the reviewer felt impelled to turn back to the author's preface to try to find out why it was written. From this we learn that the first half is a synopsis of the essential basic scientific facts as required for board examinations, while the second or clinical section is said to contain a collection of useful diagnostic and 